\title{
Median Succumbs to Persian after Three Millennia of Coexistence: Language Shift in the Central Iranian Plateau
}

\author{
Habib Borjian
}

\begin{abstract}
The so-called Central Plateau Dialects or simply Central Dialects belong to the South Median group of Northwest Iranian languages and are spoken in central Iran, where the prevailing language is Persian. Currently, vestiges of these dialects are limited to several dozen remote villages as well as to the older generation of the Jewish and Zoroastrian communities living in the cities and in diaspora. The dominant influence of Persian for more than a millennium has resulted in the ousting of the vernaculars not only in major towns but also in a majority of villages. Historical evidence suggests that Central Dialects were native to the entire central Iranian Plateau, larger towns included, until the late medieval period. The big shift may have taken place during and after the Safavid dynastic rule, perhaps as a result of forceful propagation of Shi' ism, among other economic and socio-political vicissitudes of those days. Concrete evidence becomes available only in the later nineteenth century when European travelers and local geographers began to report on the language situation of the area. These documents enable us to speculate on the patterns and rates of language shift in various regions speaking Central Dialects. This trend has been accelerating parallel with the enormous socio-economic changes in the last half century. In many villages the local dialect is moribund and becoming increasingly limited to the elders, and the extinction will be the inevitable result of the forces of modernization and globalization in general and the rapid expansion of Persian education and mass media in particular. This paper attempts to show the dynamics of language shift among Central Dialects. The possible causes of the shift within village communities is discussed, while the urban Jewish and Zoroastrian speakers receive individual attention. Part of the data comes from the author's own fieldwork. ${ }^{1}$
\end{abstract}

\section{Keywords}

endangered languages, language shift, Central Plateau Dialects, Jewish and Zoroastrian dialects, Iranian languages

${ }^{1}$ Preliminary versions of this paper were presented in the following conferences: Endangered and Minority Languages and Language Varieties, Georgetown University Roundtable on Languages and Linguistics, Washington, D.C., 3-5 March 2006; Second Iranian Linguistic Conference, Hamburg, 17-19 Aug. 2007. This paper carries on my recent articles on the Central Dialects: "The geographical distribution of 'Provincial Dialects' in the district of Isfahan" (in Persian), Iranshenasi 17, 2005; and "Isfahan xx. Geography of the Median Dialects of Isfahan," Encyclopaedia Iranica XIV, pp. 84-93. 


\section{Background: Defining Central Dialects}

Position among the languages of Iran and Iranian languages. The linguistic mosaic of Iran consists of Persian as the official language; the literary and semiliterary Turkish, Kurdish, Balochi, Turkmen, and Arabic, spread along and across the national borders; the non-literary Mazandarani, Gilaki, and Talysh along the southern shores of the Caspian Sea; and dozens of dialects spread throughout the interior of the country. The last belong to the Western branch of Iranian languages and can be divided linguistically and topographically into two main groups of Southwest and Northwest. The Southwest dialects are centered in the southern province of Fars (the Persis of the Classical sources), hence usually referred to as Perside, the group which also embraces the LoriBakhtiari subgroup and Persian, once the lingua franca of the Persianate world.

The Northwest Iranian languages consist of the aforementioned (1) Kurdish, (2) Balochi, and (3) the Caspian languages of Gilan, Mazandaran, and the Semnan region, (4 and 5) Gorani and Zaza within the Kurdophone areas, and, lastly, a series of dialects spread over a wide area in the northwest-central parts of Iran from Azerbaijan province to Isfahan and Yazd. This area is historically known as Media, thus the designation "Median" is proposed by certain scholars for these dialects (See below). Within these Median dialects, two subgroups are distinguishable: (6) the Tatic, consisting of Talysh and Tati-Azari, spoken along a belt from Lankoran on the western shore of the Caspian Sea all the way south to Qazvin, and (7) Central Dialects, the subject of this study, spreads over a large language area representing a wide variation in speech forms. There are also transition dialects, between the latter two subgroups, consisting of Vafsi, Alviri-Vidari, Tafreshi, Āshtiāni, Āmora'i, and Kahaki in the region between Hamadan, Sāva, and Qom. ${ }^{2}$

Geographical distribution. The domain of Central Dialects is clearly defined by the Central Persian Desert in the east and the massive Zagros range in the west, by and large within the modern provinces of Isfahan and Yazd. On the foothills of the Zagros lie, clockwise from the south, Khunsār, Golpāyegān, Khomeyn, and Mahallāt—historically secluded valleys relatively distant from major highways. The Karkas range, an offshoot of the Zagros, begins just east of Mahallat and west of Kashan and stretches southeastward some 200 miles, surrounded by villages speaking Central Dialects. On the west side of the Karkas, along the Qom-Isfahan highway, lie Delijān and Meyma-Jowshaqān districts, both connected to the districts of Kashan and Natanz across the 
range by a network of trails and roads leading to many secluded Medianspeaking villages. Running along the edge of the desert, the Qom-KashanYazd highway traverses the Median-speaking districts of Ardestān and Nā’in, and to a lesser degree Ardakān and Yazd. These thinly-inhabited steppe-desert districts are separated from Isfahan plain by an extension of the Karkas range, where the mountain chain lowers and spreads out, sometimes called Mārshnān after its highest peak. This section of the range is dotted on both flanks with villages speaking closely-related dialects, including those of Kuhpaya, a sizeable sub-district of Isfahan. Finally, the plain of Isfahan, irrigated by the Zāyandarud, constitutes the southern boundary of the Median-speaking province. The grouping of Median dialects in Isfahan proper is best achieved within the well-defined economic units traditionally called boluks, namely Mārbin, Borkhwār, Jarquya, Rudasht, and Kuhpaya. To the east of Isfahan is the province of Yazd with Median-speaking Zoroastrian and Jewish communities. ${ }^{3}$

A few Median-speaking localities are geographically isolated from the continuum of the Central Dialect area. These include the town of Semnān on the Tehran-Khorasan highway, and the village Sivand north of Persepolis, representing a migratory dislocation southward, perhaps in medieval times. Another distant outlier is the southeastern city of Kerman, with Zoroastrian and Jewish residents speaking vernaculars remarkably similar to the Median of Yazd. The fact that the Jewish community of Kerman emigrated from Yazd in the nineteenth century and that Zoroastrians of both cities had close ties over centuries, all suggest that the linguistic flow must have been from Yazd to Kerman, and that the presence of Median in Kerman should be quite recent. ${ }^{4}$ Lastly, aberrant forms of Central Dialects spoken by the Jewish communities of Hamadan and nearby towns mark the northwestern corner of Central Dialects' domain.

Speakers and domain of use. The speakers of Central Dialects live in more than 200 villages and in a few towns where Persian is the primary means of communication. ${ }^{5}$ These speech communities range in size from a few to several hundred households, but almost never more than 10,000 speakers. ${ }^{6}$ It would be unrealistic to calculate the number of speakers because the users of the dialects are increasingly shrinking to older generations. In larger towns such as

3 For detailed geographical grouping of these districts, see H. Borjian, 2007d.

4 Thus the designation "Kermanian" for Central Dialects, recently used by Pierre Lecoq (2002, p. 1), is untenable. See also the discussion in my review of this book in Studia Iranica 34, 2005, pp. 306-308.

${ }^{5}$ For the economic geography of the Central Dialect area, see, H. Borjian, 2007c.

${ }^{6}$ H. Borjian, 2005b; idem, 2007d. 
$\mathrm{Na}$ in and Ardestan, Median has been limited to the less affluent quarters or, as in Isfahan, to the fading Jewish communities. The domain of use varies. In the south, where Persian permeation is less advanced, native dialects are used for most in-group communication among the residents, while Persian or the local dialect may be used for inter-village communication, depending on the degree of intelligibility. ${ }^{7}$ In the north and in larger towns there is a high degree of use of Persian in all but the most intimate communication. ${ }^{8}$ A great majority, if not virtually all, of the speakers are now diglossic in their mother tongues and Persian.

Names of the dialects. Scholars of Iranian languages have generally agreed on the designation "Central Dialects" ever since its coinage at the turn of the twentieth century by Wilhem Geiger in Grundriss der Iranischen Philologie (Strasbourg, 1898-1901). A viable alternative would be "Median," or "New Median," a term initiated by Clement Huart and later revived by Ehsan Yarshater. ${ }^{9}$ It has the advantage of not only giving a historical dimension both to the language and its provenance (see Historical Perspective below), but also the convenience the adjective "Median" offers (e.g. Median-speaking villages, he speaks Median, etc.) but "Central Dialects" lacks. To distinguish Central Dialects from the Tatic group, one may call them South Median and North Median, respectively.

Each Median dialect is generally named after the community of its speakers; that is usually the village or town and sometimes the district where the dialect is spoken. The residents of the township of Kupā, east of Isfahan, call their own vernacular virže 'belonging to Vir (the local and historical name of Kupa)', and they refer to the language of the neighboring village of Qehi as kiže. Likewise, the Jewish community of Isfahan calls its dialect jidi 'Jewish.' The dialects of the Zoroastrians are usually referred to as gabri by outsiders and dari by the community itself. Speakers of the northern vernaculars of Central Dialects in Kashan province identify their shared language either as dei 'of village' or as rāji (or rāyeji), ${ }^{10}$ which implies a distant reminiscence of the city of Raga/Ray, thus relating the language of this area to the now extinct idioms around Tehran. As one travels southward towards Isfahan, the term velāti (a short form of velayati 'provincial') becomes prevalent. A curious term commonly used to distinguish the dialects is buro-beshe, for in many Central Dialects buro and beshe are the typical imperatives of 'come' and 'go,' respectively.

Krahnke, 1976, p. 58.

${ }^{8}$ Cf. Majidi, 1975, passim.

9 Yarshater, 1971, p. 17; idem, "Azerbaijan vii."

10 Yarshater, 1985. 
In turn, the villagers of Ābchuya, south of $\mathrm{Na}^{\text {in }}$, designate their dialect as osme-siga, literally 'now-thus,' two words typical of the $\mathrm{Na}$ ini subgroup of these dialects. ${ }^{11}$ The inhabitants of the plain of Rudasht refer to the dialect of their neighboring mountaineers of Kuhpaya as osme-uso 'now-go!', contrasting with their own zonon 'now' and beshe 'go!'12 These distinctions made by native speakers reflect the recognition of certain isoglottic divisions that separate Central Dialects.

Internal divisions. The grouping of Central Dialects has presented substantial problems because of numerous intersecting isoglosses and the lack of clear isoglottic bundling, a pattern which is probably the result of repeated internal migrations. Examples of crossing isoglosses are the words for 'dog' kua espa; 'thus' nezan - issin sige; 'now' haton - zogun zonun osme; 'large' gord bele - mas - gozãr. Several important morphological traits, such as the existence or lack of grammatical gender, ${ }^{13}$ differentiate the dialects. Comparativists have tried to construct a reasonable grouping of Central Dialects based on the historical development of their sound systems as well as a selective number of morphological and syntactic features. The most widely accepted classification, however, is the quadratic system of NW, NE, SW, and SE, which is indeed more of a topographical than strictly linguistic division. At any rate, no neat demarcation lines between groups can be drawn. ${ }^{14}$

As to the number of languages in the Central Dialect area, no conclusion can be drawn from the available comparative studies. A governing criterion can be the level of mutual intelligibility, which varies among the subdialects, usually attenuating with distance, and occasionally abruptly. No detailed study is available on the issue of comprehensibility among subdialects, ${ }^{15}$ but a recent survey within the district of Isfahan by the present author maintains that the traditional economic units, called boluks, essentially demarcate the mutually intelligible groups from their neighbors. ${ }^{16}$ Thus in Isfahan district alone we may assume the existence of about ten South Median languages, the number of subdialects of each ranging from one (for Sedehi, spoken in the Marbin plain to the west of Isfahan, and Jidi, the Median dialect of the Jewry of Isfahan) to dozens (for Rudashti and Kupayi).

11 Krahnke, 1976, pp. 55-56, 263.

12 Author's field notes, taken in the village Seryon in Rudasht in 2004.

13 See Yarshater, 1985.

${ }^{14}$ See Yarshater, 1985, esp. pp. 743ff.; Lecoq, 1989; Windfuhr, "Central Dialects"; Stilo, 2007. For a history of classifications, see H. Borjian, 2005b.

${ }^{15}$ Cf. Krahnke, pp. 58-59.

16 H. Borjian, 2005b. 
It may be fitting to note that only two of these ten languages, namely Gazi and Jidi, are listed in Ethnologue. ${ }^{17}$ Among the 75 living languages Ethnologue lists for Iran, nine belong to the Central Dialect group: Dari (spoken by the Zoroastrians of Yazd), Dzhidi (sic! i.e. Jidi, the Jewish dialect of Isfahan), ${ }^{18}$ Gazi, Khunsari, Natanzi, Na'ini, Semnani, Sivandi, and So(h)i. ${ }^{19}$ This list fails to identify the true distribution of the representative languages among Central Dialects; it rather lists without any comparative analysis only the dialects commonly known to linguistics worldwide.

\section{Documentation and Study of the Dialects}

The documentation of Central Dialects began in the first half of the nineteenth century, but continued more systematically during 1880-1940, and then, after the politically-troubled years that followed World War II, during the 1960s-1970s. The Revolution of 1979 denied foreigners of fieldwork, but collections by local enthusiasts and students has since been on the rise.

Among the earlier reports, the pride of place belongs to Valentin Zhukovskii's Materialy, ${ }^{20}$ embracing the dialects of Vānishān, Qohrud, Kesha, Zefra, Gaz, Sedeh, Kafrān, Sivand, and the Jewry of Kashan. Oskar Mann carried out fieldwork during the first decade of the twentieth century to much of the Central Dialect area, collecting data from Mahallat, Khunsar, Natanz, Soh, and, particularly extensively, from Na'in, as well as from Sivand and Semnan. His data was edited and published posthumously by Karl Hadank. ${ }^{21}$ The primary collectors of the dialect of Zoroastrians of Yazd and Kerman are Major

17 Ethnologue: Languages of the World is a web and print publication of SIL International, a Christian linguistic service organization which studies lesser-known languages primarily to provide the speakers with Bibles in their native language. Its latest edition (2005) contains statistics for 6,912 languages and gives the number of speakers, location, linguistic affiliations, etc. It is currently the most comprehensive existing language inventory, along with the Linguasphere Register. However, the accuracy of data in the Ethnologue for many languages has been disputed by various scholars. This author has found the Ethnologue quite inaccurate in every respect for the languages spoken in Iran; for instance, the speakers of Persian and Azerbaijani Turkish languages in Iran are estimated as 36 and 37 percent, respectively; the invariable population figure of 7,033 is mentioned for the speakers of Gazi, Na'ini, Natanzi, and Sivandi. See http://www. ethnologue.com.

${ }^{18}$ It is incorrectly interpreted in Ethlologue as Judeo-Persian, while the latter refers commonly to the forms of Persian written in Hebrew script.

${ }^{19}$ http://www.ethnologue.com.

20 Zhukovskii, 1888-1922.

${ }^{21}$ Mann and Hadank, 1926. 
D.L.R. Lorimer ${ }^{22}$ and Vladimir Ivanow; ${ }^{23}$ the latter's works also cover the dialects of Anārak, Khur and Mehrajān along the edge of Central Desert. Arthur Christensen's fieldwork, ${ }^{24}$ covering Natanzi, Farizandi, and Yārandi, remains the only one of its kind for the latter two idioms. The briefer works are those of Ruben Abrahamian ${ }^{25}$ on the Jewish dialects of Isfahan and Hamadan, Sir Harold Bailey ${ }^{26}$ on Ardestani, and Ann K.S. Lambton ${ }^{27}$ on Meyma'i and Jowshaqani. Wilhelm Eilers' extensive texts from Gaz, Khunsar, and Sivand, collected from 1936-40 and then in the $1960 \mathrm{~s},{ }^{28}$ render these idioms the most comprehensively documented of all Central Dialects.

A fresh beginning was made in the late 1960s, when Pierre Lecoq conducted fieldwork on the dialects of Qohrud, Abuzeydābād, Abyāna, Tār, Bādrud, $\mathrm{Na}$ 'in, Anarak, Ardestan, Varzana, and Sivand. ${ }^{29}$ Karl John Krahnke visited sixteen villages in 1970-72 within the triangle of Natanz-Na in-Isfahan, concentrating on the vernaculars of Nohuj, Na in, Natanz, and Ardestan. His documentation, however, remains unpublished, save for the relevant materials he used in his unique comparative study. ${ }^{30}$ Studies of Ehsan Yarshater and Donald Stilo on Central Dialects appear under various entries in Encyclopaedia Iranica. The engagement of the Persian Academy of Letters (Farhangestān) in the study of dialects in the 1970s yielded several short but useful studies, including Majidi's survey, ${ }^{31}$ with sample glosses from the last generations of speakers in the Kashan-Mahallat-Meyma area; Bahram Farahvashi's Khuri glossary, ${ }^{32}$ and Haideh Sahim's masters' thesis on the Hamadani Jewish, ${ }^{33}$ among others. Postgraduate theses have been growing exponentially in the last two decades, yet many suffer from inaccuracy and methodological problems. To these, one may add publication of glossaries, idioms, and poems by native pundits on their home villages. ${ }^{34}$

22 Lorimer, 1916; idem, 1928; Vahman and Asatrian, 2002.

${ }^{23}$ Ivanow, 1926; idem, 1927; idem, 1934-39.

${ }^{24}$ Christensen, 1930.

25 Abrahamian, 1930.

26 Bailey, 1935.

27 Lambton, 1938.

28 Eilers and Schapka, 1976-88.

29 Lecoq, 1979.

${ }^{30}$ Krahnke, 1976.

31 Majidi, 1975.

32 Farahvashi, 1976.

${ }^{33}$ Note also a comparative study of Jewish dialects of Hamadan, Isfahan, and Shiraz in Sahim, 2002.

${ }^{34}$ For a comprehensive bibliography of documentations, see Windfuhr, "Central Dialects"; H. Borjian, 2007d. 
Two related nationwide projects have been conceived towards generating a linguistic atlas for Iran based on audio-recorded materials. The first one began in 1974 at Farhangestan to identify dialects nationwide based on a questionnaire consisting of 150 glosses and twenty sentences. ${ }^{35}$ As the revolution soon interrupted the project, the collected data were transferred to the Cultural Heritage Foundation, which has published four volumes, all on Isfahan province. ${ }^{36}$ The second project, sponsored by the Agriculture Corps (Jehäd-e keshāvarzi) since 1998, is by and large a replication of the former project: it incorporates similar strategy, techniques, and questionnaires, except that the number of sentences is now doubled. The greater part of the survey had been completed in 2005, when I visited their Tehran headquarters; however, the poor quality of workmanship and audio-recordings limit their merit to the mere identification of the language in each surveyed locality, when the audiocassettes are not lost or field notes are legible.

The published linguistic materials, substantial as they may appear, constitute a tiny fraction of the documentation needed before Central Dialects vanish altogether. Most of the community speeches remain unknown, and an inventory of the localities in which Central Dialects are spoken is yet unavailable. Documentations of quality are indeed few and are limited largely to those of the earlier efforts made by the scholars of Iranian philology. The main thrust of scholarly interest in these dialects has been comparative, with the intention of clarifying areal or genetic relationships. There have as yet been relatively few attempts to synchronize the work of traditional disciplines with the global enterprise of language documentation. As to the socio-linguistics of the area, the only study known to me is the brief sketch Karl Krahnke included in an introductory chapter of his otherwise comparative dialectology. ${ }^{37}$

\section{Historical Perspective}

The provenance of modern Iranian languages corresponds to a large extent to areas where Middle and Old Iranian languages were once spoken. Among the living Iranian languages, Persian is the only one with an established history from its ancient to its modern form; historical evidence is insufficient to establish as close a relation between the various chronological stages of other

35 Thamara, 2002.

36 Shenāsāyi-e guyeshhā-ye Irān (1983-2000), which has published only a fraction of the collected data: 19 glosses and two short sentences for two representative dialects in each rural district.

37 Krahnke, 1976, pp. 14-20. 
Iranian languages. ${ }^{38}$ The geographical position, however, may help us to arrive at certain conclusions regarding Central Dialects.

Ancient Media and the Median. The earliest known language spoken in the Central Dialect area is Median, the language of the Medes who migrated into the Iranian Plateau, as the Persians did in the early first millennium B.C.E. Median is generally assumed to be the official language during the dynastic rule of the Medes (ca. 700-559 B.C.E.), but no text has been discovered in Median; only numerous non-Persian words in the Old Persian texts are commonly presumed to be Median, while other Median forms are preserved in the Akkadian versions of the Achaemenid inscriptions and in classical works ${ }^{39}$ for instance, Herodotus (1.110) cites the Median word for 'dog' as spaka, various forms of which are current in many Central Dialects of our time. ${ }^{40}$ Subsequently, Old Median, as we know it today, is little more than a set of reconstructed words that clearly mark its Northwest Iranian characteristics, contrasting with Old Persian that belongs to the Southwest group. This linguistic evidence alone is inadequate to link Median with any specific later dialect or group of dialects of the same language family. ${ }^{41}$ As there are no solid isoglottic features that distinguish Median from proto-Parthian, the linguistic interpretation of Old Median (already with many dialects) can be made as broad as to consider it an ancestor to Parthian and all other Northwest Iranian languages, including Central Dialects, the Tatic and Caspian groups, GoraniAwromani, and Zaza. ${ }^{42}$

While linguistic analysis alone is insufficient to hold up the designation "New Median" for Central Dialects (and the Tatic group as well), the geographical factors neatly support such designation: (1) The facts that no mass migration was ever reported into the Median territories after that of the Medes and that there is no historical evidence that the population of Media was ever dislocated on a significant scale, suggest that Central Dialects and Tatic should have ultimately descended from ancient varieties of Median, and (2) no major ancient or medieval inscriptions have been found in the Central Dialect area to suggest that any other major Iranian language has ever been spoken there

\footnotetext{
${ }^{38}$ For an overview, see Skjaervø.

39 See Schmitt, esp. pp. 86-90.

${ }^{40}$ Median $s p a-k a$ - compares with Old Persian $s a-k a->$ New Persian $s a g$ 'dog'. It typifies one of the earliest isoglottic splits $(s p-s)$ that separates Persian and other Perside languages from the rest of languages of Iranian stock.

${ }^{41}$ Gernot L. Windfuhr, review of Yarshater, 1971, in JAOS 92, 1972, pp. 370-374; Krahnke, 1976, p. 51.

${ }^{42}$ Kurdish and Baluchi, however, do not belong to the Median group, for they carry Perside elemets in their oldest phonological strata. See MacKenzie; Windfuhr, 1975.
} 
by a sizable community. Even if we choose to ignore language-related arguments altogether, the mere fact that the area covered by Central Dialects and Tatic corresponds roughly to the old Greater and Lesser Media, respectively, provides sufficient grounds to use the designation "New Median" for these dialects. ${ }^{43}$

Medieval Fahlavi survivals. The earliest solid linguistic evidence in the Central Dialect area surfaces in medieval times. The Islamic works written between the tenth and fifteenth centuries have several citations of words and phrases from the native dialects of the area that correlate closely to the living Central Dialects. Commonly referred to as "Pahlavi" or "Fahlavi"44 (i.e. Parthian), these medieval dialects had an oral literary tradition, with specimens quoted in some anthologies of Persian poems. The fact that Fahlavi dialects, as the continuation of Old Median dialects, have certain linguistic affinities with Parthian suggests a good deal of language mixture with Parthian, another Northwest Iranian language which belonged originally to the super-province of Parthia, the present Khorasan, but was gradually spread westward into Media. ${ }^{45}$ Another major source of influence on the Central Dialects has been Persian, the lingua franca of the region for a millennium. Persian is not only a distant maternal cousin of Central Dialects (as is the case for any other Iranian language spoken on the Plateau) but in a sense their father as well: it has increasingly been flooding the dialects, primarily their vocabulary and, more recently, permeating their morphological and syntactical structure.

The Fahlavi survivals reveal important facts about the language of the urban centers that are now entirely Persophone. Quotations in two eleventh-century works from the vernacular of Isfahan and its environs ${ }^{46}$ leave little doubt that the city had not yet fully adopted Persian by that time, even if it was to become the hub of Persian literature in the centuries to come. In fact, Fahlavi must have been spoken in the city as late as the fourteenth century, for we find three poems in the native speech of Isfahan in the collected works of Owhadi (12741338), the prominent Persian poet from Isfahan. ${ }^{47}$ There are similar Fahlavi survivals from Kashan, another Persianized city of the Central Dialect area,

43 Please note that claims of some kind of connection between the ancient Media and Median language on the one hand and Kurdistan and the modern Kurdish dialects on the other, raised by Kurdish pundits, have been refuted by D.N. MacKenzie; Windfuhr, 1975.

${ }_{44}$ Clement Huart called these dialects "Muslim Pahlavi” to distinguish it from Zoroastrian Pahlavi-that is Middle Persian. For a discussion, see H. Borjian, 2008b.

45 For this reason these languages may properly be called Median-Parthian; see H. Borjian, 2007e.

46 Tafazzoli, 1971.

47 Adib Tusi, 1963; Borjian, 2009. 
whose old vernacular survived through its Jewry until a few decades ago. ${ }^{48}$ Therefore, it is safe to consider Central Dialects as being native to the entire area, larger towns included, until late medieval times. The fact that the southern and southwestern parts of Isfahan province show no survival of Median is due to the dominance in these regions, before the spread of Persian, of other languages, chiefly of the Perside Lori-Bakhtiari family.

Safavid rule and thereafter. It is difficult to establish when and how the larger part of the population of the Central Dialect area shifted to Persian. A late nineteenth-century report ${ }^{49}$ on the localities around Isfahan where "provincial" dialects were spoken shows a general picture not radically different from the areal pattern of the dialects today. Therefore, the lion's share of linguistic integration must have occurred before the nineteenth century but not earlier than the fourteenth century, when Owhadi wrote his dialect poems. A contributing factor to language shift here might have been the political status of Isfahan as the capital of Safavid Persia from ca. 1600-1722, during which time a rather abrupt shift to Persian could have taken place in the city, with subsequent radiation outward in all directions, overlying the native dialects up to a radius of $50 \mathrm{~km}$ or so.

It is indeed not difficult to explain how the shift came about in Isfahan when we consider the metropolitan status of the Safavid capital, which attracted bureaucrats, craftsmen, religious leaders, and merchants not only from throughout Persia but also from virtually the entire civilized world, so much so that immigrants outnumbered the native townspeople at least tenfold. ${ }^{50}$ How could this enormous brassage not leave behind Persian as the language of the

48 Yarshater, 1974.

49 Janab, 1992, p. 128.

50 Jean Chardin, who lived for ten years in the Safavid capital, offers, in his Voyages, a detailed and vivid description of "the greatest and most beautiful town of the whole Orient," in which there were to be found followers of all religions and merchants from the whole world. Indians involved in the banking business alone numbered no fewer than ten thousand. The commercial character of the Safavid metropolis can be seen in other figures offered by Chardin: there were 162 mosques and 1,802 caravanserais within the city walls and 500 more caravanserais without. Accordingly, for every mosque there were more than eleven inns, a ratio that has become reversed today: 73 inns of all ranks vs. more than 1,500 mosques in the district of Isfahan (2003 data). Moreover, according to Chardin, there were twelve to fourteen thousand prostitutes publicly registered with as many more who worked on their own. And this was in the same city that was the capital of Shi' ism, attracting religious scholars from all Muslim lands; the Jabal 'Amel of Lebanon alone was the provenance of virtually all leading jurists of Isfahan in those days. The population of this enormous city, estimated by Chardin to match that of London (i.e. circa 650,000 ), grew to well over one million, according to other reports, by the end of Safavid rule. See Ferrier, tr. and ed., 1996, passim; H. Borjian, 1993; idem, 2007a. 
town? The countryside too, the source of bread for the city, could not have escaped from language shift, at least partially. There is indeed a clear link between the agricultural districts included in the water regulation system ${ }^{51}$ and those which shifted to Persian in the upper and middle course of the river Zāyandarud. The topographic patterns of the shift may also be linked to the existence of the elaborate underground canals known as qanāt, which usually required state investment and sponsorship; thus the boluk of Borkhwār which received its water exclusively from qanāts is left with no more than three Median villages, while over seventy percent of the settlements in the rainfed boluk of Kuhpāya have preserved their dialects.

The downfall of the Safavid state by the Afghan invasion of Isfahan in 1722 was followed by the most dramatic demographic decline in the history of the city and its environs. The invasion itself and the consequent famine and destruction of the rural infrastructure resulted in the dwindling of the population from over a million souls just before the invasion to some 50,000 in 1796 , i.e. a population decline of over twentyfold in less than a century. ${ }^{52} \mathrm{In}$ the countryside there is evidence of population shifts in Jarquya district, located southeast of Isfahan: the population replacement in the village of Mālvājerd following the Afghan invasion, and the forced relocation of Persophone tribes from Fars under the Zand dynastic rule in the late eighteenth century ${ }^{53}$ could have resulted in language shift. Even more evidence such as this may surface when historical documents are carefully scrutinized.

Did religion have a share in the language shift? Why in the bigger towns, such as Isfahan, Kashan, and Yazd, are the native dialects spoken exclusively by the Jewish and Zoroastrian communities, while all Shi ite residents have shifted to Persian? Does this have anything to do with Persian being the means of intensive religious propaganda carried out under the Safavid dynastic rule? As is well-known, the language of the pulpit and its associated preaching styles, the genres of rowza-kh $h^{w} \bar{n} i$ and marthiya, have been well developed, taught, and practiced only in formal Persian-at least during the last couple of centuries in central Persia. More facts are needed before one can draw conclusions in this regard, but the religious factor appears to be the main cause of language shift in other large cities of Iran, such as Shiraz, which has abandoned its old Perside vernacular in favor of Persian, and Tabriz, which is entirely Turkish.

Another venue to look into is the communication patterns attached to trade, clearly the route of much Persian influence on the native idioms. Whether

51 The allocation of the Zayandarud's water to various districts around the city of Isfahan is documented in the Sheikh Baha'i's tumār, dated 1527. See Lambton, 1937-39.

52 See H. Borjian, 1993.

53 Shafi i Nikabadi, 1997, pp. 150, 446ff.; H. Borjian, 2005 b. 
urban peddlers traversed the countryside or villagers visited the urban market centers, the means of communication was Persian, and the $b \bar{a} z \bar{a} r i$ language could easily and quickly flood the dialects. ${ }^{54}$ Neither must one overlook the carpet industry, which boomed in the 1870s in response to the growing markets in the West, and became a significant source of income for rural households in much of the Central Dialect area. This brought most villages into contact with the towns on an unprecedented scale. ${ }^{55}$

\section{Rates and Patterns of the Shift}

Assuming that the entire central Persia once spoke Median dialects, let us first see what parts thereof have been more successful in resisting Persian. In terms of the number of settlements, the center of gravity is east of Isfahan in the Rudasht-Kuhpaya area. The most resilient of all appears to be Rudasht, with an uninterrupted continuum of nearly 50 Median-speaking villages. ${ }^{56}$ In the neighboring Kuhpaya-Zefra-Sagzi area, in the southern foothills of Marshnan, more than three-quarters of the total 137 settlements are reported to have maintained their native speech, while only about half of Jarquya's 23 villages have resisted Persian. Outside of Isfahan district, the Meyma-Jowshaqan area yields the highest ratio: 19 Median-speaking localities of the total 23. The ratio in the rest of Kashan district is no more than a quarter of the 73 settlements. ${ }^{57}$ In the northern and western parts of the province, Median survives in not more than a few isolated communities. Thus, the language shift seems to be more intensive as one travels from the SE to NW. This pattern can be attributed partly to the fact that the northern areas have been in closer contact with the capital city of Tehran, around which the Tatic dialects used to be spoken, but are now totally extinct. The Zagros districts of Golpayegan, Khunsar, and Faridan have been under the influence of both Lori and Turkic.

Persian permeation has been far more advanced in larger towns. Isfahan in the south and Kashan in the north, the largest urban centers of the area, have lost their native vernaculars for centuries, with the exception of their Jewish residents. Of medium-sized towns Golpayegan turned to Persian long ago, but the nearby Khunsar was reported in 1988 as having retained its native dialect

\footnotetext{
Ivanow, 1934-39, p. 38.

See, i.a., H. Borjian, 2007b.

${ }^{56} \mathrm{H}$. Borjian, $2007 \mathrm{~d}$.

57 The statistics are calculated based on reports on individual areas in Shenāsāyi-e guyeshhä-
} ye Irān. 
in certain quarters. ${ }^{58}$ The incomplete shift in Khunsar is possibly because the town lost much of its former importance in the second half of the twentieth century, causing a temporary deceleration in language shift. Na'in appears to have had a similar fate, as Median was restricted to the older and lower-class residents in the early $1970 \mathrm{~s} .{ }^{59} \mathrm{Natanz}$, another small town, was rapidly becoming Persophone already in the early 1930s and had lost much of its Median characteristics forty years later. ${ }^{60}$ It appears that as a town grows in terms of population and urbanism, its native dialect becomes more vulnerable.

Language maintenance in villages depends on the geographic location and arrangement. Those located in the vicinity of cities have been far more vulnerable to language loss. This trend is well attested east of Isfahan in the subdistrict of Rudasht, where the Persian-Median frontier shifted a few villages further eastward from $1977^{61}$ to 2004 , when I visited the area. ${ }^{62}$ A parallel trend is observed in Kashan district. ${ }^{63}$ The proximity to major roads ${ }^{64}$ has also been instrumental to language shift; a salient example, on the modern IsfahanTehran highway, is the village Murchakhwort, where the local dialect was dying out in the 1970s. ${ }^{65}$ In Ardestan district the rural communities along the Kashan-Yazd highway on the desert plain are almost entirely Persianized, contrasting with those in higher valleys. For such areas as the piedmont district of Kuhpaya, which exhibits a pattern of Persianization along certain mountain valleys, further field investigation is needed, as migration into this remote district is unlikely. Finally, the shift to Persian seems to be far more advanced in isolated villages than those forming interconnected clusters, as in Rudasht, Zefra, and Jowshaqan.

\section{Role of Ethnic and Social Identities}

Ethnic relevance. The level of endangerment of languages and dialects of Iran appears to be correlated with ethnic or tribal identity of their speakers. The Kurds and the Baloch show a strong sense of ethnic identity as well as admiration for their mother tongue. These ethnolinguistic groups as well as the Turkish and Arabic speakers of Iran find additional political expression across

58 Shenāsāyi III, pp. 64-65.

59 Krahnke, 1976 , p. 58.

${ }^{60}$ Krahnke, 1976, pp. 77, 112.

${ }_{61}$ Shenàsāyi II, pp. 117-21.

${ }^{62}$ H. Borjian, 2007d.

63 Majidi, passim.

64 Siroux, Chapter 1.

${ }_{65}$ Comparing the reports by Majidi, p. 13, and Shenāsāyi II, p. 36. 
national borders. The Lors and Bakhtiaris of the southern Zagros are proud of their tribal affiliations, and their dialects appear less vulnerable to Persian, though concrete facts are yet to be collected. Towards the opposite end of the spectrum, the Caspian languages of Gilan, Mazandaran, and Semnan exhibit a high level of Persianism, partly due to a low sense of ethnic identity on the part of their millions of speakers. ${ }^{66}$ As for the speakers of Central Dialects, the outstanding fact is that they stand on the lowest step of the identity ladder, lacking even the mere ethnolinguistic title the speakers of Tatic possess due to their presence within or near a Turcophone milieu.

In fact, the population of the Central Dialect area is ethnically undifferentiated. There is no indication of any historical or contemporary tribal organization or affiliation. The language of a village or town, whether Median or Persian, plays no role in its identification, neither by the inhabitants nor by outsiders; an individual outside his hometown is usually identified with his provenance rather than his mother tongue. Nor is religion a differentiating factor (with the obvious exception of the Jews and Zoroastrians; see below), as the speakers of Central Dialects not only confess to Shi ism, the state religion, but the area has been known historically as the heartland of Shi ism in Persia. Interestingly, many contemporary Grand Ayatollahs carry the toponyms of the Central Dialect area in their surnames: Khomeini, Mahallati, Golpayegani, Khunsari, Kashani, etc. Moreover, no sign of regionalism has ever been recorded in the Central Dialect area. "In general, the people speak only of family, village, and national values and interests, recognizing only the political and administrative realities of the modern nation above and beyond those of the village." ${ }^{67}$ The above is not too surprising given the fact that in the past half millennium central Iran has been the core of what is generally understood as Persian culture, and its population is the most conservative guardians of national traditions and, therefore, zealous antagonists to modernization.

Prestige. In this respect, Central Dialects are probably no more disadvantaged than other languages and dialects spoken in Iran, where Persian is regarded as the language. This is not the place to talk about the invincible assertion of Persian throughout the Persianate societies in the past millennium; suffice to mention that forms of literary expression in the region has been almost exclusively in Persian, and that literary Persian is generally understood as the only form worthy of being written, taught, and preserved. Thus, it is common practice on the part of local collectors of dialects to justify their curiosity by

${ }^{66}$ For a sociopolitical discussion on the Mazandarani language, see M. Borjian, 2005, pp. 65-74.

67 Krahnke, 1976, p. 20. 
stating that their works may eventually contribute to the richness of Persian vocabulary by means of revitalizing those words or purer varieties that have been forgotten in Persian but are retained in the dialects. Those who write poetry in Central Dialects usually aim to cast their poems into the exact meters of classical Persian prosody, even with partial success. ${ }^{68}$ It is therefore not surprising that dialect literature tends to resort to a kind of tawdry vulgarity far less commonly found in formal Persian literature. ${ }^{69}$ Isolated remarks recorded by past collectors of Central Dialects show predominantly negative attitudes held by speakers of the dialects toward their mother tongue, though they range from the belief that a given language is punishment given by God, to a feeling that the language was a precious inheritance allowing for broader communicational opportunities. ${ }^{70}$ The fact that Central Dialects are shared with the urban Jewish community makes some villagers in the vicinity of Isfahan suppose that they may have a Jewish lineage—-something they are not particularly proud of. The fact that some speakers of Central Dialects, usually more educated ones, hold the conviction that their "Pahlavi" language is a purer and older form of Persian does not alter the balance of prestige that is rooted in social realities.

There is also a socio-economic aspect to the question of esteem. Being spoken by villagers or the lower-class town dwellers, Central Dialects are seen as the low-prestige variety. The dialects are disdained by the younger generation and practically shunned by school-aged children. My personal observation also suggests that younger women hold a more negative view of their native idiom than male speakers generally do. Villagers of the central Persia are generally "penurious, credulous and satisfied," those of Abyana, located at the end of the long and ardent valley of Barzrud in the central Karkas range. Its peculiar architecture and the distinctive attire of its women attract tourists from Tehran, where the younger generation of Abyana'i, typically affluent, live and work. Yet language has no role in this distinct identity.

${ }^{68}$ Cf. Yarshater, 2001, esp. p. 246; H. Borjian, 2005a; H. Borjian and M. Borjian, 2008.

${ }^{69}$ H. Borjian, 2005a.

${ }^{70}$ Krahnke, 1976, p. 62. Zhukovskii quotes the following popular rhyme from his rural informants who had added a fourth tongue to the famous trio: Lafz-lafz-e Arab ast; torki honar ast; färsi shakar ast; zabān-e mā [...] khar ast 'Language par excellence is Arabic; Turkish is (a work of) art; Persian is sugar; our language_crepitus podicis asini' (Zhukovskii, I, p. viii).

71 Millspaugh, p. 256. 


\section{Modernization and Language Shift}

While Iran as a whole underwent an enormous social and economic change in the past century, the adjustment has been even more profound in the backward communities speaking Central Dialects. The change began to be felt in the villages by the 1960s, when the Land Reforms broke the backbone of millennia-old Persian feudalism and caused many former peasants to leave their home villages for cities to work at paying jobs. Another contemporaneous reform was the dissemination of literacy by means of a corps of young army recruits (Sepāh-e dānesh) assigned to villages; in consequence, for the first time in history, Persian was introduced in a large scale to Median-speaking villagers at an early age. The older generation would have been excluded from this Persian 'invasion' had the transistor radio not been made available to a majority of rural households at a low price by the end of the decade. Notwithstanding these facts, the outcome of modernization was still meager even a decade after the reforms had been introduced. When Karl Krahnke visited the area to document Central Dialects, the occupation of the villagers was still almost exclusively agriculture and carpet weaving, and the villages consisted of traditional mud-brick huts with little signs of modernization, including electricity. ${ }^{72}$

The rural conditions had altered beyond recognition when I began to visit the area in the late 1990s. Soon after the Revolution of 1979, men of the Rural Construction Corps arrived in virtually every village of the Central Dialect area and began to build roads, mosques, schools, and houses, brought electricity and telephone lines to the remotest of hamlets and set up a network of producer-and-consumer cooperatives. I came upon few households whose members were exclusively occupied in agriculture. Few younger males were not involved in a business or trade which did not in one way or another require routine trips to the nearby towns. As the weekend or a major holiday approaches, the traffic flow from cities to villages is noticeable. The enormous movement of sections of the rural population into towns and cities has contributed to the dispersal of rural communities and brought them into increased contact with the Persian language. There was hardly anyone in the villages I visited who could not speak Persian fluently.

A powerful cause of language shift in the Central Dialect area has been compulsory mass education in Persian. It is true that Persian was the means of education even in olden times, yet formal education was largely unavailable in remoter villages and more so to women, who eventually transmit the native

72 Krahnke, 1976, p. 19. 
language to their children. In 1956, the literacy rate was as low as 15 percent for Isfahan province. With the enormous expansion of the educational system in the following decades, the literacy rate for the age group 6-39 approached 98 percent in $2002 .{ }^{73}$ Moreover, the statistics bear witness to the gradual tapering of the gender gap: girls' school enrollment increased from 19 percent in 1953 to slightly more than half by the end of the century. ${ }^{74}$ In the post-revolutionary period, several colleges have been established in several townships, attracting students from all over the country and leading to greater diffusion of Persian at the expense of native dialects.

While there has been no institutional support for Central Dialects, neither is there any indication that the use of these dialects has been discouraged by the government or by the speakers of Persian in general. Nevertheless, the villagers in Kamandān east of Isfahan told me that their clergyman had warned them not to teach the vernacular to their children lest they never become proficient in Persian. Whether this is a personal conviction of an individual mullah or part of the cultural policy advocated by the Shi ite seminaries centered at Qom needs further investigation.

\section{Jewish and Zoroastrian Speakers}

Among the speakers of Central Dialects, religious minorities warrant particular sociolinguistic attention for several reasons. Unlike the rural speakers of Central Dialects who otherwise have no distinct identity from their fellow countrymen, the religious minorities of Iran are both socially and officially distinguished from the Shi'ite mainstream. The Jewish speakers of the vernaculars were, until recently, the only groups who had preserved the native Median in larger urban centers such as Isfahan, Kashan, and Hamadan. These Jewish communities, and the Zoroastrians of Yazd, have for centuries been living in Persian-speaking towns, and, consequently, they fall into a different social context from the rest of the speakers of Central Dialects who live by and large in relatively isolated villagers and townships. As the more liberal policies of the Pahlavi dynasty (1925-79) facilitated social integration and brought prosperity for the minority groups of the country, most of the Jews and Zoroastrians moved to Tehran, which proved more hospitable and less prone to sectarian prejudices, as well as financially more attractive to these economically dynamic minorities. Another wave of mass migration occurred during

${ }^{73}$ See M. Borjian and H. Borjian, 2007.

74 Ibid. 
and after the Islamic Revolution of 1978-79, when religious minorities left for various countries and many eventually settled in North America. Having occurred within a generation or two, these migrations have meant a virtual end to the dialects, at least for the second generation of immigrants who have grown up in societies (Tehran or abroad) that did not encourage the use of the vernaculars.

Jewish communities. Jewish communities are as deeply rooted in Persian society as the rest of Persians. Most urban centers of Persia used to have a Jewish quarter, typically by the side of the city's citadel, under the protection of the rulers who supported the Jewry for their expertise in commerce. There remains from medieval times a considerable body of Persian literature in Hebrew script known as Judo-Persian, ${ }^{75}$ including some of the Biblical translation and commentaries in archaic forms of Persian. The Jewish residents of the central Persian towns generally preserved the native language that was lost otherwise to Persian. These include: (1) Hamadan and the nearby towns Nehāvand, Malāyer, and Tuysekān, and Arāk, all geographically isolated from the continuum of Central Dialects; (2) Kashan, Khomeyn, Golpayegan, and Isfahanin these towns, too, the use of Median was exclusive to Jewish neighborhoods; (3) Khunsar, Delijan, and Mahallat, where Median was shared with the Muslim residents; and (4) Yazd and Kerman, where Median is also preserved by the Zoroastrians. Most of these longstanding Jewish communities were on the verge of disappearing already by 1970. The larger centers of Jewish population speaking a Central Dialect included Kerman and Yazd with about 450 Jewish souls each, Hamadan with 800 , and Isfahan with 2,500 to 3,000. ${ }^{76}$ The larger part of the Jewish populace of these towns had already moved to Tehran, which hosted some 60,000 Jews at the time, or else they had immigrated to Israel, a trend that has been continuing to this date.

Among the Median-speaking Jewish communities, that of Isfahan has been by far the largest and one of the longest standing. ${ }^{77}$ Its historical significance is implied by the fact that Isfahan was known in the early Islamic centuries as Johudestān/Yahudiya 'Jewish town,' referring to the large Jewish settlement on the site which eventually became the Jubāra quarter in central Isfahan. The

75 Judo-Persian is often confused with the Median dialects spoken by the Jews.

76 Yarshater, 1974.

77 The establishment of the Jewish colony of Isfahan is ascribed to those exiled by the Babylonian king Nebuchadnezzar, according to Talmudic tradition (s.v. "Isfahan," The Standard Jewish Encyclopaedia). The Middle Persian Shahristānīha i Erān states that the Sasanian king Yazdegerd I (r. 339-420) settled Jews in Isfahan at the request of his Jewish wife Shōshāndukht. See Markwart, 1931, p. 19, par. 47. 
Jewish population of the city remained sizeable throughout the Middle Ages, some 15,000 when the total population was about $100,000 .^{78}$ From this historical backdrop remain some twenty synagogues in the old quarter of Jubāra alone, as well as emāmzāda Esmāi il, which is shared with Muslims, and the mausoleum of Pir-e Bakrān near Isfahan, revered by Jewish pilgrims from throughout the country. A rapid decline of population has been witnessed in the mid-twentieth century: of the 10,000-12,000 Jews who had lived in Isfahan in 1948, only about 2,500 remained in $1968,{ }^{79}$ and the number of functioning synagogues dropped to thirteen by $1961 .{ }^{80}$ The current size of the community, estimated at about 2,000 souls by my local informants in recent years, may appear not radically different from the 1968 estimate; however, if population growth by natural birth is taken into account, the ongoing element of emigration, particularly to Israel, becomes more apparent. This process becomes even more evident in the number of operating synagogues, which has dropped to merely two or three in Jubara. On the other hand, the modern synagogue of Kèter Dāvud in central Isfahan is the chief congregation of the community as it attracts, according to my informants, up to 500 people every Saturday morning. This in turn reflects the aerial shift in the Jewish population of the town: only a third of them still live in Jubara; the rest have moved to more affluent middle-class neighborhoods around the thoroughfare of Chārbāgh Avenue ${ }^{81}$ and, accordingly, gradually assimilating into the gentile population.

Indeed, social integration and education are prime factors in language shift among the fading Jewish community of Isfahan. Eager to avoid distinctive marks in public, the younger generations often consider their own dialect a feature reminiscent of their former inferior status. Traditionally peddlers and spinners living in ghettos, their condition improved substantially during the Pahlavi period, with many integrating into the mainstream socio-economic life and beginning to participate in virtually all walks of social life. In these developments, education and connection to the international Jewish movement have a role. The opening of the Alliance Israélite Universelle in 1901 was a turning point for modern education in the city. More Jewish schools were established in Isfahan by the ORT and Ozar ha-Torah in the first half of the twentieth century. Already in 1961, 150 pupils attended Jewish high school

78 Sources on population of Isfahan and its Jewry are provided in H. Borjian, 1993.

79 An estimate from the mid-1950s: 5,700 to 6,100, including 2,000 adults, 2,400 school age, and 1,500 preschool children; see 'Abedi, 1955, p. 220.

80 "Isfahan," Encyclopaedia Judaica 9: 78-79.

${ }^{81}$ For the distribution of Jewish households among various neighborhoods of Isfahan, see the map in Shafaqi, 2003, p. 402. 
and 897 attended elementary school; other children attended non-Jewish schools, while there were about 50 Jews at the University of Isfahan. ${ }^{82}$

No longer operating in any domain of language use, the Jewish dialect of Isfahan is facing a dead-end fate. My aged informant told me that he uses Jidi but only occasionally, to exchange several sentences with a few men of his own age group. In the Persian Jewish community of New York City, there are still people who speak the dialect more or less fluently, but again, it rarely happens that they come across another fluent speaker to have a conversation in the vernacular.

Zoroastrian communities. The Zoroastrians of Persia may share their fate with the Jews in terms of incipient language loss, but not necessarily for the exact same causes and circumstances. Once scattered throughout Persia, the Zoroastrian communities shrank considerably during the theocratic reign of the later Safavids, to the extent that, by the late nineteenth century, they were by and large limited to Yazd in central Persia and Kerman to its southeast. For many centuries, Yazd was the Zoroastrian stronghold with some two dozen villages and a quarter of the town itself populated by the followers of the "good religion." 83 The Zoroastrian population was estimated by European travelers of the early twentieth century to be about 5,000 in the town of Yazd, another 5,000 in its villages, more than 2,000 in Kerman, and 500 in the adjoining villages. ${ }^{84}$ During the ensuing decades most Zoroastrians migrated to Tehran, the ever-expanding capital, which, according to an estimate, hosted 19,000 of the total 25,000 Zoroastrians of Persia in 1975..$^{85}$ As successful entrepreneurs and professionals, Zoroastrians were in the forefront of the mass emigration during the Islamic Revolution. Many settled in North America, particularly in California and New York, where they have established their fire temples and endowments following their rich philanthropic traditions, often in collaboration with the Parsee co-religionists who have emigrated from India.

The strong sense of pride among the Zoroastrian community has left its impression on the awareness of and attitude toward their native dialect. Zoroastrians are regarded as the inheritors of one of the oldest religions and the glorious Sasanian traditions otherwise lost during the Arab invasion of the country in the seventh century of our era. The dialect spoken by the community is not usually percieved as merely one of Central Dialects as it really is,

82 “Isfahan," Encyclopaedia Judaica 9: 78-79.

83 Bailey, 1936.

${ }^{84}$ Vahman and Asatrian, 2002, pp. 13-15.

85 Windfuhr, "Central Dialects." 
but as one of the oldest and purest of all living languages in the country. It is indeed one of the earliest collected by European travelers and the most extensively documented of all Central Dialects by the Iranians. Both the self-esteem and outside attention have probably been responsible for the positive view the Zoroastrians hold toward their idiom. To have an appropriate name for their dialect, they have replaced the label Gabri, on account of its negative connotation, ${ }^{86}$ with Dari, which is in fact a prestigious medieval name for the Persian language; more recently the appellation Behdinān "the people of the Good Religion" has been extended to refer to the dialect as well. Although Yazdi has many distinct subdialects, the remarkable similarity between the Median dialects of Yazd and Kerman, and the intermingling of the Zoroastrians of two cities in Tehran and abroad has yielded a coine that allows all Persian Zoroastrians to use it as a means of internal communication. In the fire temple of New York City casual communication is conducted in that vernacular. Moreover, attempts has been made to establish classes for children in this dialect in order to keep the otherwise vanishing language alive. Whether or not these efforts can preserve the Zoroastrian dialect is yet hard to tell, as the Iranian Zoroastrian communities in diaspora generally consider Persian their principal heritage.

\section{Conclusion}

This essay claims not to be more than a general overview of the ongoing language shift in central Iran that raises some questions for future studies. Examination of sources lead to the conclusion that the central-western Iranian Plateau, corresponding to the ancient Media Major, had not yet become Persianized to any large degree before the medieval period, but was inhabited by speakers of the dialects known today as the Tatic and Central Dialect groups. When did the process of shift begin and how far did it advance throughout various stages of history? It is known but poorly how New Persian infiltrated Media beginning in the second millennium of the Common Era, though Persian did not fully assert itself until after the Safavids established their theocratic regime. As was the case with Turkish in Azerbaijan, a big shift to Persian might have taken place in the urban centers of central Persia in modern times due to the forces which still need to be established by examining historical sources for possible mass migrations, the role of trade and religion, state and local language policies, among others.

${ }^{86}$ The word gabr/gawr had the original sense of 'man, Zoroastrian' but is used as 'infidel, fire worshipper' by Muslims. 
Many Central Dialects have been replaced by varieties of Persian, some in recent memory, and for some others the shift came about centuries ago. While our understanding of the language situation in the remoter past is largely based on speculation, concrete evidence comes into view in the nineteenth century, thanks to the notes left by curious travelers and then by anthropologists and linguists. Comparing older reports against more recent ones reveals the fact that Persian has been quite active in undermining the local dialects in many villages and towns of the Central Dialect area, perhaps more rapidly than ever before. While some geographical patterns of the language shift were identified in this paper, many questions remain — for example, the reason why the contemporary shift is far more evident in the northern and western parts than in the Isfahan district. A deeper analysis of the extent of communicative patterns, particularly the role of economy and the marketplace, may lead to better understanding of the causes and patterns of language shift.

The causes of language shift within the modern setting include lack of ethnic and tribal identity, lack of prestige due to low social and economic status of the speakers of Central Dialects, and finally the new and irreversible forces concomitant with modernization. In the past few decades, for the first time in history, transportation, urbanization, mass media, and public education have breached the relative isolation which had provided a haven for the survival of the language and other cultural traits unique to the speakers of Central Dialects. The small number of speakers of each speech community in the omnipresence of Persian certainly adds to the level of language endangerment. The urbanized Jewish and Zoroastrian speakers of Central Dialects began to be absorbed into the mainstream of the Persian-speaking middle class, another universal condition that generally leads to language shift. Mass emigration during and after the Islamic Revolution has been a trend specific to these speakers of Central Dialects. Generally speaking, Central Dialects are no longer subject to gradual disappearance, which varied in scale relative to the historical conditions, geographical configuration of villages or social status of the speakers, as used to be the trend before the advent of modernization; we are now facing a condition that suggests progressive ousting, leading to the extinction of these idioms within a generation or two, unless counteractive forces alter the equilibrium in favor of survival.

What might these preservationist forces be? Some kind of institutional support, such as state policy for maintaining endangered languages, is not likely to materialize in the foreseeable future, before it is too late. A more viable scenario would be a change of attitude among the speakers of the dialects towards their mother tongues. The population speaking these dialects, formerly illiterate peasants or lower-class urban dwellers, are now skilled workers, educators, and professionals. While education can be held responsible as a 
catalyst in ousting dialects, it has also caused some speakers to be less indifferent than their ancestors were towards their native culture, language included. This trend has been observed sporadically for some time now. A small group of former residents of Sedeh in Isfahan attempted to preserve the language, in part by publishing poetry. ${ }^{87}$ The fact that the Zoroastrians in diaspora have established classes to teach their tongue to their children is of great importance, since the pulse of a language lies in its younger generation. There are local enthusiasts who have been collecting words, phrases, and poetry, and graduate students, mostly native speakers, have written scores of university projects on these dialects. These publications, notwithstanding their mediocre status from a scholarly perspective, have been on the rise in the last few decades, partly due to the cheap cost of print, something that may help at least some of the dialects eventually gain literary status, another positive sign for language maintenance.

Realistically speaking, however, these forces of preservation appear scanty when compared with the social realities mandating language shift. If maintenance of the highly endangered and moribund languages of central Iran is beyond practical help, the very last chance still remains to document what is left, and thus make a contribution to preserving the dialects, if only in archive form.

\section{References}

Hasan 'Ābedi, Esfahān az lehāz-e ejtemāi i o eqtesādi, Tehran, 1955.

Ruben Abrahamian, Dialectologie iranienne. Dialectes des Israelites de Hamadan et d'Ispahan et dialect des Baba Tahir, Paris, 1930.

M. Adib Tusi, "Se ghazal-e esfahāni az Owhadi-e marāghi," Nashriya-ye Dāneshkada-ye adabiyāt-e Tabriz 15, 1963, pp. 387-400.

Harold W. Bailey, “Iranian Studies. IV,” $B S O(A) S$ 7, 1935, pp. 769-78.

Idem, "Yazdi," $B S O(A) S$ 8, 1936, pp. 335-61.

Habib Borjian, "Esfahān dar tārikh-e Irān," Rahāvard, ser. no. 33, 1993, pp. 74-95.

Idem, "Tashih-e motun-e guyeshi: Divān-e Darvish 'Abbās-e gazi," Iranshenasi 17, 2005a, pp. 320-337.

Idem, "Joghrāfiā-ye guyeshhā-ye velāyati-e Esfahān,” Iranshenasi 17, 2005b, pp. 466-486.

Idem, "Isfahan," in M.R.T. Dumper and B.E. Stanley, eds., Cities of the Middle East and North Africa: A Historical Encyclopedia, Santa Barbara, 2007a, pp. 147-149.

Idem, "Isfahan xiii. Traditional Crafts," Encyclopaedia Iranica XIV, 2007b, pp. 48-55.

Idem, "Isfahan xiv. Modern Economy and Industries," Encyclopaedia Iranica XIV, 2007c, pp. 55-67.

Idem, "Isfahan xx. Geography of the Median Dialects of Isfahan," Encyclopaedia Iranica XIV, 2007d, pp. 84-93.

87 Krahnke, 1976, p. 62. 
Idem, "The Median-Parthian Group of the Northwest Iranian Languages," in H. Borjian, ed.,

Third Biennial Convention, Association for the Study of Persianate Societies, Tbilisi, Georgia,

8-11 June 2007. Abstracts and Presidential Address, Yerevan, 2007e, pp. 59-62.

Idem, "Jarquya, District and Dialect," Encyclopaedia Iranica XIV, 2008a, pp. 582-588.

Idem, "The Extinct Language of Gorgan: Its Sources and Origins," Journal of the American

Oriental Society 128, 2008b, forthcoming.

Idem, "When and How Did the Vernacular of Isfahan Shift from Median to Persian?" 2009, forthcoming.

Habib Borjian and Maryam Borjian, "Twenty-five Mazandarani quatrains," Nawabi Memorial Volume, ed. M. Jaafari Dehaghi, Tehran, 2008, forthcoming.

Maryam Borjian, "Bilingualism in Mazandaran: Peaceful Coexistence with Persian," Languages, Communities, and Education: A Volume of Graduate Student Research, New York: Teachers College, Columbia University Press, 2005, pp. 65-74.

Maryam Borjian and Habib Borjian, "Isfahan xv. Education and Cultural Affairs," Encyclopaedia Iranica XIV, 2007, pp. 67-71.

Arthur Christensen, Contribution à la dialectologie iranienne I, Copenhagen, 1930.

Wilhelm Eilers and Ulrich Schapka, Westiranische Mundarten aus der Sammlung W. Eilers, 3 vols., Wiesbaden, 1976-88.

Bahrām Farahvashi, Vāzhanāma-ye khuri, Tehran, 1976.

Ronald W. Ferrier, tr. and ed., A Journey to Persia: Jean Chardin's Portrait of a Seventeenth-century Empire, London and New York, 1996.

V. Ivanow, "Two Dialects Spoken in the Central Persian Desert," JASB 21, 1926, pp. 405-31. Idem, "Notes on the Dialect of Khur and Mihrijan," Acta Orientalia 8, 1927, pp. 45-61.

Idem, "The Gabri Dialect Spoken by the Zoroastrians of Persian," Rivista degli studi orientali 16, 1934, pp. 31-97; 17, 1938, pp. 1-39; 18, 1939, pp. 1-59.

Āqā Mir Sayyed 'Ali Jenāb, al-Esfahān, Isfahan, 1992.

Karl J. Krahnke, Linguistic Relationships in Central Iran, Doctoral dissertation, University of Michigan, 1976.

Ann K.S. Lambton, "The regulation of the waters of the Zāyande Rūd,” BSOAS 9, 1937-39, pp. 663-673.

Idem, Three Persian Dialects, London, 1938.

Pierre Lecoq, Le dialecte de Sivand, Wiesbaden, 1979.

Idem, "Les dialects du centre de l'Iran," in R. Schmitt, ed., Compendium Linguarum Iranicarum, Wiesbaden, 1989, pp. 313-326.

Idem, Recherches sur les dialectes kermaniens (Iran central), Acta Iranica 39, Belgium, 2002.

D.L.R. Lorimer, "Notes on the Gabri Dialect of Modern Persian," JRAS, 1916, pp. 423-89.

Idem, "Is there a Gabri Dialect of Modern Persian?" JRAS, 1928, pp. 287-319.

David Neil MacKenzie, "The origins of Kurdish," Transactions of the Philological Society, 1961, pp. 68-86.

Mohammad-Rezā Majidi, Guyeshhā-ye pirāmun-e Käshān o Mahallāt, Tehran, 1975.

Oscar Mann and K. Hadank, Kurdisch-persische Forschungen 3/1. Die Mundarten von Chunsar, Mahallat, Natanz, Nayin, Samnān, Sivand und Sô-Kohrûd, Berlin and Leipzig, 1926.

J. Markwart, A catalogue of the provincial capitals of Eranshahr: Pahlavi text, version and commentary, ed. G. Messina, Rome, 1931.

A.C. Millspaugh, The American Task in Persia, New York, 1925.

Haideh Sahim, "Languages and dialects of the Jews of Iran and Afghanistan," in Human Sarshar, ed., Esther's Children: A Portrait of Iranian Jews, Beverly Hills, Cal., 2002, pp. 283-294.

Rudiger Schmitt, "Andere altiranische Dialekte," in R. Schmitt, ed., Compendium Linguarum Iranicarum, Wiesbaden, 1989, pp. 86-94.

'Ali Shafi i Nikabadi, Garkuya: Sarzamin-i nāshenäkhta bar karān-e kavir, Isfahan, 1997. 
Sirus Shafaqi, Joghrāfiā-ye Esfahān, Isfahan, 2003.

Maxim Siroux, Anciennes vois et monuments routiers de la region d'Isfahan, Cairo, 1971.

Shenāsāyi-e guyeshhä-ye Irān, 4 vols., Tehran, 1983-2000.

Donald Stilo, "Isfahan xxi. Provincial Dialects," Encyclopaedia Iranica XIV, 2007, pp. 93-112.

Idem, "A Description of the Northwest Iranian Project at the Max Planck Institute for Evolutionary Anthropology," at http://www.eva.mpg.dellingualfiles/NWIran.html; cited on Nov. 1, 2007.

Ahmad Tafazzoli, "Ettelā‘āt-i darbāra-ye lahja-ye pishin-e Esfahān,” Nāma-ye Minovi, Tehran, 1971, pp. 85-103.

Y. Thamara, "Mo'arrefi-ye do tarh-e melli-e guyesh-shenāsi," in H. Reza'i Baghbidi, ed., Majmu'amaqālāt-e nokhostin hamandishi-e guyesh-shenāsi dar Irān, Tehran, 2002, pp. 135-142.

F. Vahman and G. Asatrian, Notes on the Language and Ethnography of the Zoroastrians of Yazd, Copenhagen, 2002.

Gernot L. Windfuhr, review of Ehsan Yarshater's A Grammar of Southern Tati Dialects, in JAOS 92, 1972, pp. 370-374.

Idem, "Isoglosses: A Sketch on Persians and Parthians, Kurds and Medes," in Acta Iranica. Monumentum H.S. Nyberg II, Acta Iranica 4-7, Tehran and Liege: Brill, 1975, pp. 457472.

Idem, "Western Iranian Dialects," in R. Schmitt, ed., Compendium Linguarum Iranicarum, Wiesbaden, 1989, pp. 294-294.

Idem, "Central Dialects," Encyclopaedia Iranica V, pp. 242-252.

E. Yarshater, A Grammar of Southern Tati Dialects. Median Dialect Studies I, The Hague, 1971.

Idem, "The Jewish communities of Persia and their dialects," Mélanges Jean de Menasce, Louvain, 1974, pp. 455-466.

Idem, “Azerbaijan vii. The Iranian language of Azerbaijan," Encyclopaedia Iranica III, pp. 238-245.

Idem, "A Peasant Marriage: A Poem in Chāli by Mohammad-Bāqer 'Āmeli," Studia Iranica 30, 2001, pp. 245-289.

V.A. Zhukovskii, Materialï dlya izuchesniya persidskikh' narechiy, 3 vols., St. Petersburg, 18881922. 